\title{
Sense of Community and Social Life in the Fishing Neighbourhood of Gurunagar, Jaffna, Sri Lanka.
}

\author{
Arthy Yogalingam 1,a, Janaka Wijesundara ${ }^{2, b}$, \\ $1 \& 2$ Department of Architecture, University of Moratuwa, Sri Lanka \\ a. arthy156@gmail.com, b.jawij@yahoo.com
}

\begin{abstract}
The role of space and neighbourhood layout in the creation of local communities have been less well undersrtood. Research has developed indices for evaluating the sense of community and social life, but has not focused on the significance of neighbourhoods. Sense of community and social life are related to social cohesion, areas of inquiry in sociology, psychology and the built environment. Social life studies focus on city centers or periphery areas; while sense of community studies of sociologists and psychologists focus on neighbourhoods. The role of the built environment on the sense of community and social life of neighbourhood however is less well understood.

This paper explores the sense of community and social life of Gurunagar fishing neighbourhood and investigates how a particular fishing community plays a vital role in their own territory in terms of physical, social, economic and environmental aspects. It highlights its magnitude in achieving a successful neighbourhood. The research was conducted through observations, photographic surveys, spatial analysis, interviews and discussions with those who live in the selected case study area.
\end{abstract}

Keywords: sense of community, social life, neighbourhood.

\section{Introduction}

Sense of community and social life are two key concepts of the built environment, which have been discussed with regard to the effect of the physical characteristics on the residents' socializing patterns. Sense of community is a feeling of belonging and shared interests among members of a community while social life of a place refers to the patterns of socializing behaviours among residents. Social life has been mostly discussed in the literature of the built environment discipline, whereas sense of community has been mostly the subject of several studies in disciplines such as sociology and psychology (Fig 1). 


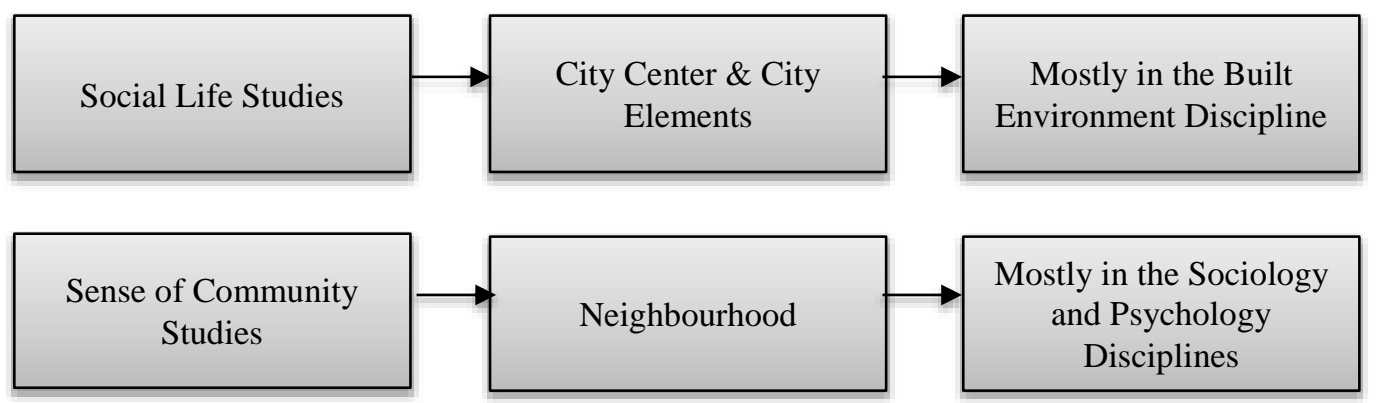

Fig 1: Studies on Sense of community and Social life in cities and neighbourhoods Source: Author

Social life studies have mostly focused on city centres. Therefore, when it comes to residential environments, the number of these studies decreases dramatically and it can be considered as a gap in the literature of the built environment (Fig 1). This study suggests that both concepts of social life and sense of community can be included in neighbourhood studies. The aim of this study is to develop a better definition and understanding of these concepts. This paper, by developing a conceptual framework on neighbourhood's socializing patterns can contribute to future community studies and especially neighbourhood planning research. The study will explore the established key theories around sense of community and social life from the built environment perspective and will investigate how the related theories can be applied to the neighbourhood environment. Physical characteristics in the neighbourhood environment can influence the ways in which residents in a neighbourhood environment feel a sense of community.

\section{The Background}

In the past, there has been a closer relationship between public life and a neighbourhood's environment. Historical neighbourhoods grew little by little, in accordance with their residents' changing needs. Residents' requirements had to be satisfied within the neighbourhood's boundaries and through their commitments to the local communities. Therefore, historically, neighbourhoods were placed with a high degree of socializing patterns and sense of community among residents. Two occurrences changed this process: the shift to industrial cities and the shift to the media and virtual societies

First, the shift to industrial societies had a major impact on the way people were living and socializing. Industrialization caused people to migrate to cities in search for jobs and social welfare. Parallel to the virtual societies, there is still a need for face-toface interactions and non-virtual local communities which neighbourhoods can provide the opportunity for their development. The built environment in the neighbourhood may enhance the chance of encounters through walking and stationary activities. Therefore, there is a need, in the literature of public life studies, for research on the social life and community patterns in residential neighbourhoods.

Social life studies started in the 1960s, when criticism on modern architecture and urbanization was at a peak due to the neglect of social needs and marginalizing of 
human interactions. Consequently, public life studies were initiated by scholars such as Jacobs (1961) and Gehl (1987), who are considered as the key authors in this area of knowledge.

\section{Theoretical Orientation}

\section{Sense of Community}

Sense of community is a concept in the field of community psychology, which has been defined as "the sense that one was part of a readily available mutually supportive network of relationship" (Sarason, 1974). In the early 1970s, Sarason pointed to the popularity of the books with the themes of loneliness, isolation and the feeling of not belonging. He described this occurrence as "a decline in psychological sense of community" (Cochran, 1994). McMillan and Chavis (1986), whose study is frequently used in the psychology literature, argue that sense of community is composed of four elements: 1) Membership, 2) Influence, 3) Integration and fulfillment of needs, 4) Shared emotional connections.

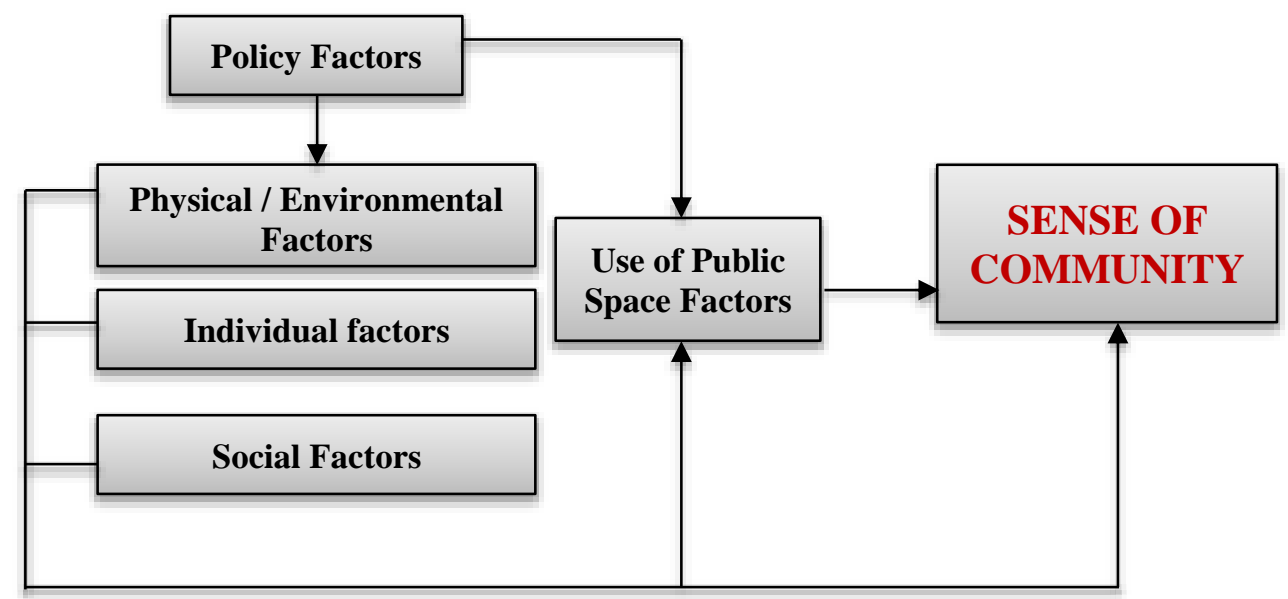

Fig 2: Conceptual model of relationship between public space and sense of community

Source: Francis et al., 2012

According to community psychologists such as Plas and Lewis (1996), environmental factors may be crucial for the development of a sense of community in urban communities. Cochran also argues that planners are able to preserve and strengthen a neighbourhood's sense of community through both social policies and physical design strategies (Cochran, 1994).

Therefore, from these debates it can be concluded that the built environment is able to influence the feeling of sense of community either directly or indirectly through increasing the chance of interactions among residents (Francis et al., 2012). Informal interactions in neighbourhoods lead to some acquaintanceships which are known as weak ties in the literature (Granovetter, 1973). High levels of weak ties among neighbours are believed to increase the occurrence of strong ties and social affiliation (Granovetter, 1973; Greenbaum, 1982). 


\section{Conceptual Framework}

Scholars from the built environment discipline are trying increasingly to develop frameworks to facilitate the study of sense of community in neighbourhoods. Francis et al. (2012) have developed a conceptual model for the relationship between public space and the sense of community. They define four categories of policy, physical environment, individual and social factors that directly or indirectly affect sense of community (see Fig. 2). Kim and Kaplan (2004) have also developed a framework to study sense of community regarding physical aspects of neighbourhoods. The framework identifies four domains, which are hypothesized to relate to an important aspect of residents' feeling that they belong to the community (see table 1).

Table 1: Sense of Community: Theoretical Dimensions (Source: Kim and Kaplan, 2004).

\begin{tabular}{|c|c|c|c|c|}
\hline \multicolumn{5}{|c|}{ DOMAINS OF SENSE OF COMMUNTTY } \\
\hline & $\begin{array}{l}\text { COMIUNIT } \\
\text { ATTACHMENT }\end{array}$ & $\begin{array}{l}\text { COMMIUNITY } \\
\text { IDENTITY }\end{array}$ & $\begin{array}{c}\text { SOCIAL } \\
\text { INTERICTION }\end{array}$ & $\overline{\text { PEDESTRIANISM }}$ \\
\hline $\begin{array}{l}\text { PRIMIARY } \\
\text { ACTION }\end{array}$ & $\begin{array}{l}\text { Bonding with } \\
\text { community }\end{array}$ & $\begin{array}{l}\text { Identifying } \\
\text { (with) } \\
\text { community }\end{array}$ & $\begin{array}{l}\text { Being involved } \\
\text { in community }\end{array}$ & $\begin{array}{l}\text { Knowing } \\
\text { community }\end{array}$ \\
\hline \multirow{5}{*}{$\begin{array}{l}\text { SUB } \\
\text { COMIPONENTS }\end{array}$} & $\begin{array}{l}\text { Community } \\
\text { satisfaction }\end{array}$ & Uniqueness & Neighbouring & Walkability \\
\hline & Connectedness & Continuity & $\begin{array}{l}\text { Casual social } \\
\text { encounter }\end{array}$ & $\begin{array}{l}\text { Pedestrian } \\
\text { propinquity }\end{array}$ \\
\hline & $\begin{array}{l}\text { Sense of } \\
\text { ownership }\end{array}$ & Significance & $\begin{array}{l}\text { Community: } \\
\text { participation }\end{array}$ & Mass transit \\
\hline & $\begin{array}{l}\text { Long term local } \\
\text { integration }\end{array}$ & Congruence & Social support & $\begin{array}{l}\text { Pedestrian } \\
\text { scale/street } \\
\text { activities }\end{array}$ \\
\hline & & Cohesiveness & & \\
\hline
\end{tabular}

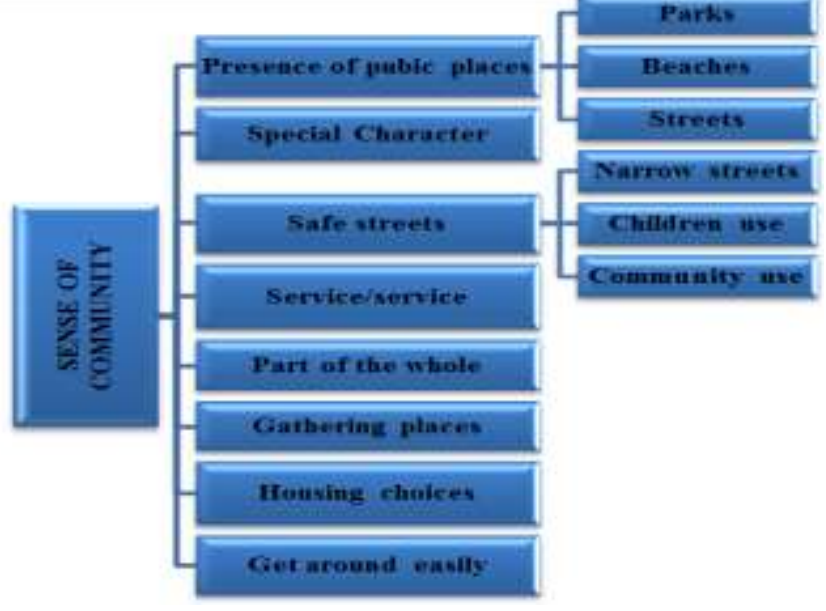

Fig 3: Model of the built environment influence on feeling a sense of community Source: Author

\section{Social Life}

Sociability is a primary role of public places in cities and neighbourhoods. Good public places in cities provide an avenue for communication and socializing behaviours. Public life has been acknowledged as everything that occurs in public spaces between buildings: sitting, chatting, walking, cycling, running, standing and playing, which form 
the "life between buildings" (Gehl, 1987). For architecture, being alive is about being complex: forming, transforming and maintaining a structural organization that consists of multiple constituents arranged in specific patterns (Bhat, 2014). Only a few studies have focused on the sociability of residential environments. However some of the factors that have been studied regarding the public life of city centres and streets are applicable to residential environments (see Fig. 4).

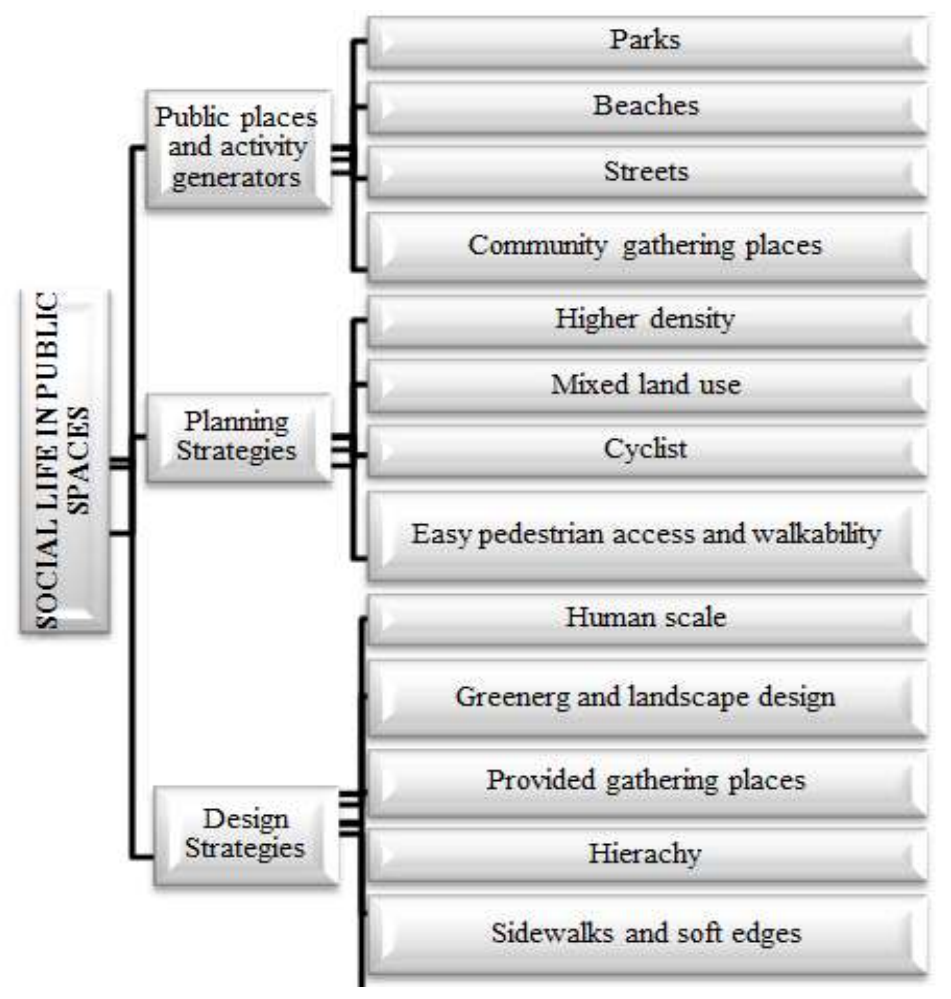

Fig 4: Physical characteristics that affect the social life in public places Source: Author

Comparing social life studies to sense of community studies (see Fig. 3 and 4) shows that built environment characteristics that promote the social life in cities are similar to those discussed in the sense of community sections. There are two accounts for this similarity. First, since the built environment must provide an avenue for encounters and increase the chance of interactions for both a social life and a sense of community, the contributing factors are mostly similar. Second, in the built environment literature, the meanings of sense of community and social life have sometimes been misinterpreted and misplaced. In the literature of the built environment, the boundary between the meaning and interpretation of the terms sense of community and social life is not rigid and clear. 


\section{Sense of Community and Social Life in a Neighbourhood}

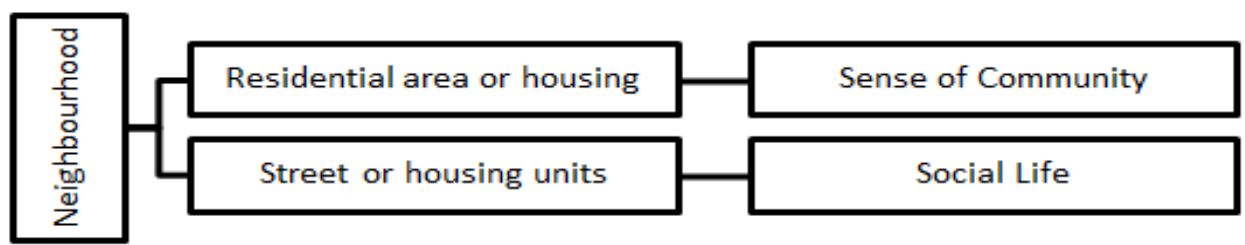

Fig 5: Model of the sense of community and social life of neighbourhoods Source: Author

Neighbourhoods are the connecting points between homes and the city. Therefore, the social life of a neighbourhood is the interface of the private life of residents and the social life of the whole city. Neighbourhoods have been defined in several ways and with several characteristics. Brower (1996) accounts three dimensions for a neighbourhood: ambience, engagement and choicefulness. Engagement refers to the extent of intensity among residents and the presence of facilities and features that foster or inhibit the interactions. Engagement is the interface of the private home life to the public city life. Neighbourhood environment provides a two-fold opportunity for socializing behaviours among residents. Neighbourhoods are a combination of housing units and extended housing units (Brower, 1996). The residential street can provide the avenue for community interactions and neighbouring behaviours (sense of community); while the commercial street as the most public space in the neighbourhood provides the chance of encounters between residents and non-residents (social life) (Fig 5).

Residential streets are the fulcrums of feeling a sense of community among residents. A residential environment is where neighbours get to know each other; they change their relationships from strangers to acquaintances, neighbours or friends. In other words, they become a community. According to Unger and Wandersman, 'neighbouring' consists of a social component, a cognitive component and an affective component. The affective bonds between neighbours are categorized in three forms: sense of mutual aid, sense of community, and attachment to place (Unger \& Wandersman, 1985) (Fig. 6).

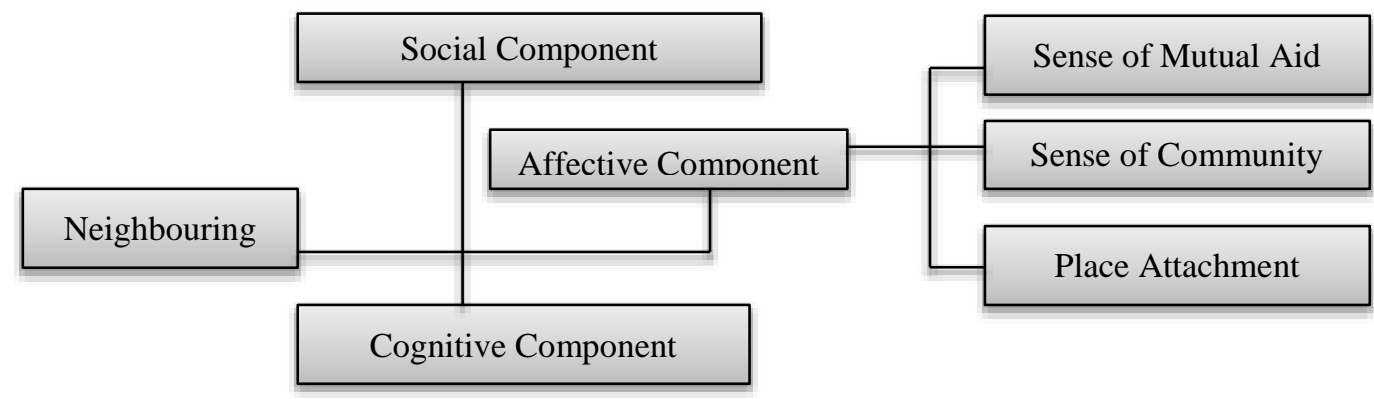

Fig 6: Neighbouring components

Source: Unger and Wandersman, 1985. 
Studies conducted on the sense of community of neighbourhoods have not separated the residential environment from the commercial, or non-residential environment. There are few key studies that have been partially dedicated to the social life in the residential environments. Appleyard (1981) in the study of three streets in Italian residential neighbourhoods in America noticed that the traffic has affected the number of interactions in the streets. As can be seen in Fig. 7, it can be concluded that traffic affects people's perception of the home territory and this will indirectly affect social life of residential streets.

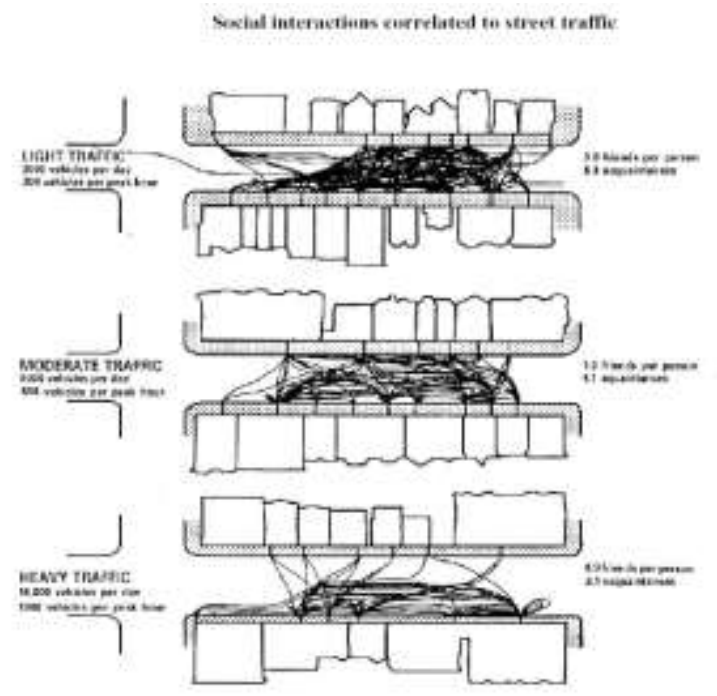

Fig 7: Study of neighbourhoods interactions in relation to traffic Source: Appleyard, 1981

A recent study by Mehta shows that commercial streets in neighbourhoods can influence the social, land use and the physical qualities (Mehta, 2007 \& 2013). Encouraging these qualities will affect the public life of commercial streets and the entire neighbourhoods. To improve the social life of commercial streets, Mehta (2013) has developed a design guideline that can be seen in Fig. 8.

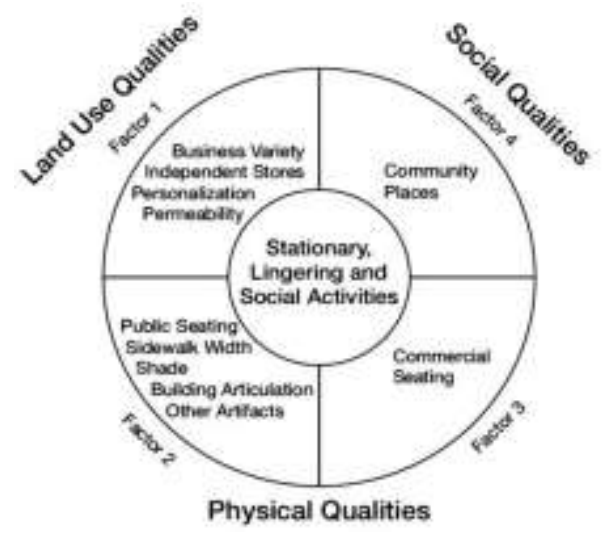

Fig 8: Characteristics of the neighbourhoods' commercial street Source: Mehta, 2013 


\section{Research Methodology}

As graphically represented below, this research evolved and developed through an in-depth research process which consisted of the stages of the preliminary study, study area selection and research study while gaining discipline, knowledge, training, and practice in the process of examination.

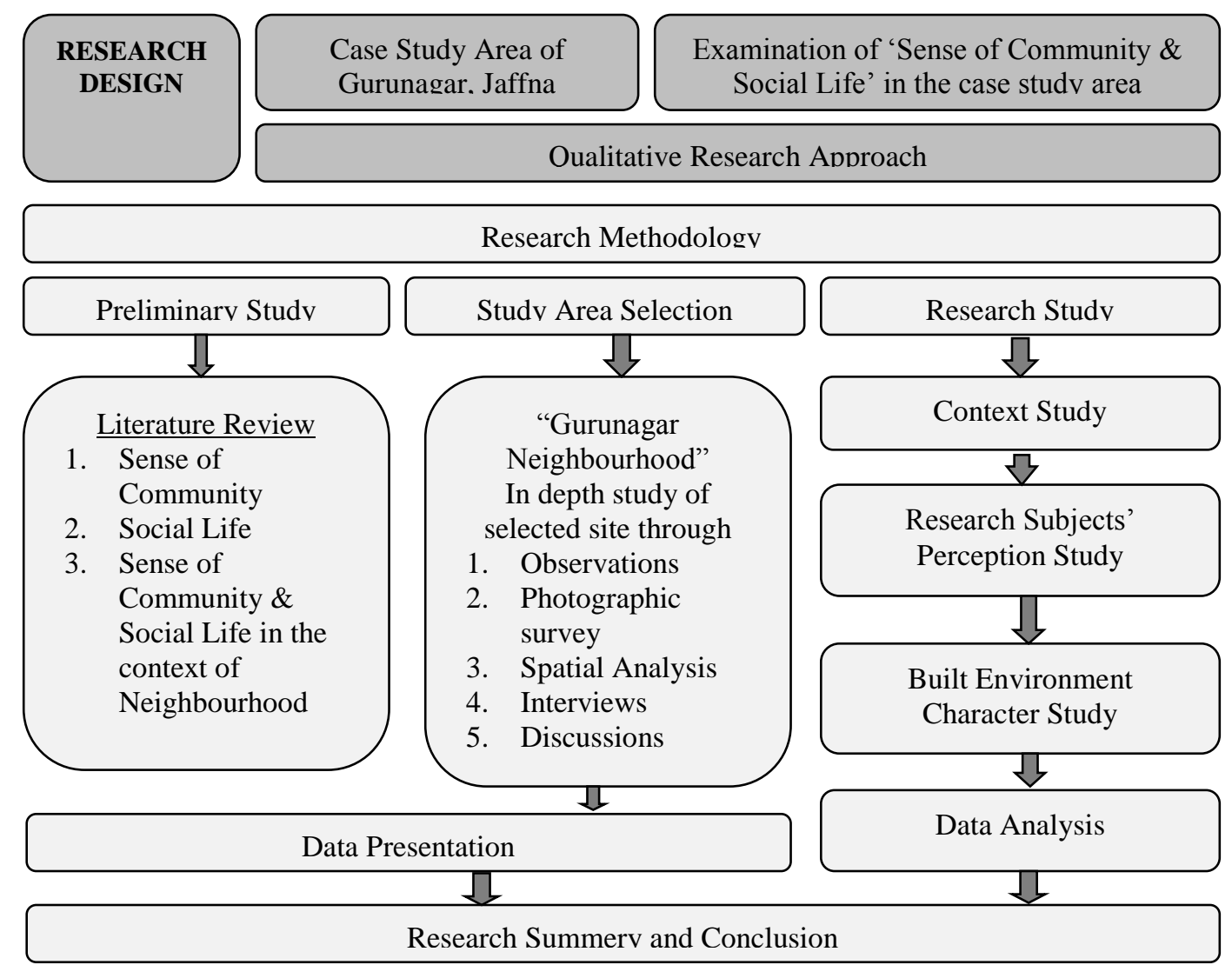

Fig 9: Research Methodology (Source: Author)

First, direct observations were made to study about the Gurunagar fishing neighbourhood and the surrounding. Daily routine activities, social life and people's connections were observed. This was followed by the unstructured interviews and open discussions which allow questions based on the interviewee's responses and proceeds like a friendly non-threatening conversation. Here, it focuses on the people those who live in the Gurunagar area and get the ideas about their social life.

This was followed by an activity survey which is an investigation about the characteristics of the Gurunagar area. This survey attempted to observe the activity pattern, its functions and also the interconnections between different spaces. A photographic survey was accomplished to record what really happened on the ground level and to observe the functional spaces of the neighbourhood. Through an organized photographic survey in the case study area, the human behavioral aspects and 
conflicting situations were identified. The activities and symbolic features were also recorded in photographs, sketches and maps.

\section{Limitations}

Examining the neighbourhood is a broad conception. In this study, only the sense of community and social life were analyzed based on qualitative research data. But there are other methods and guides that can be used to analyze the neighbourhood by applying quantitative research techniques. This qualitative research will help to lay the fundaton and do further studies related to neighbourhoods by applying some quantitative techniques to understand them more fully in the future. This research will help understand the local people and their social life before applying the quantitative techniques.

\section{Analysis and Findings}

Sense of Community and Social Life in the Gurunagar Neighbourhood

\section{The Gurunagar Neighbourhood}

Gurunagar is a coastal village in the Jaffna city in Northern Sri Lanka with a concentration of high density housing on a land extent of $0.37 \mathrm{Sq} . \mathrm{km}$. The population of Gurunagar is nearly 6,200 as recorded in 2017. The suburb is populated mainly by Catholic Sri Lankan Tamils, engaged in sea activities. The neighbourhood helps to define a neighbourhood by strongly contributing to a sense of place and helps promote a sense of community. It also offers neighbourhood residents a destination point located at the relative centre of the neighbourhood near the Jaffna town center. This is the main fishing neighbourhood which has a high amount of fishing population when compared to other fishing villages. Predominantly, this neighbourhood is meant for the fishing community and nearly $90 \%$ of the people engage in fishing. So the identity reflects the fishing community.

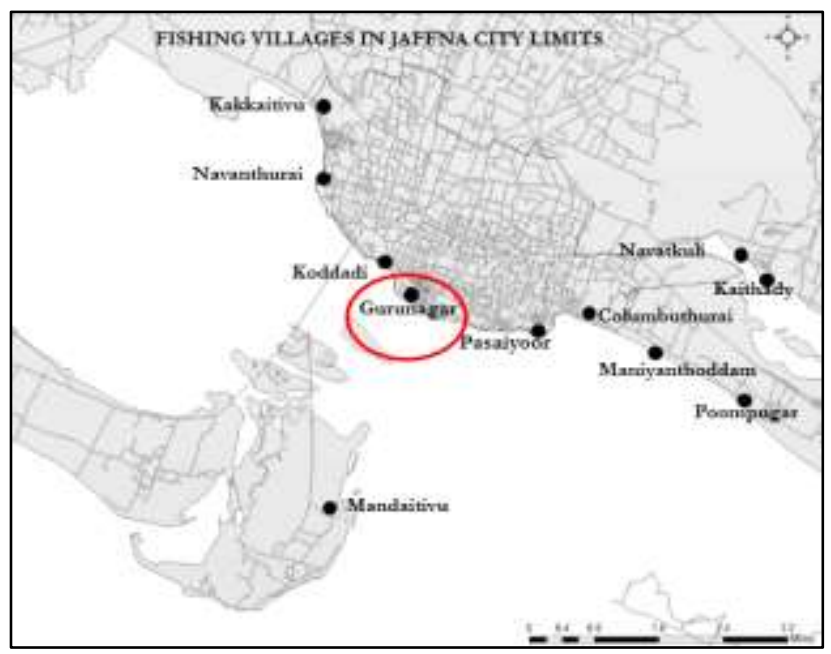

Fig 10: Location of Gurunagar Fishing Village (Source: Author). 


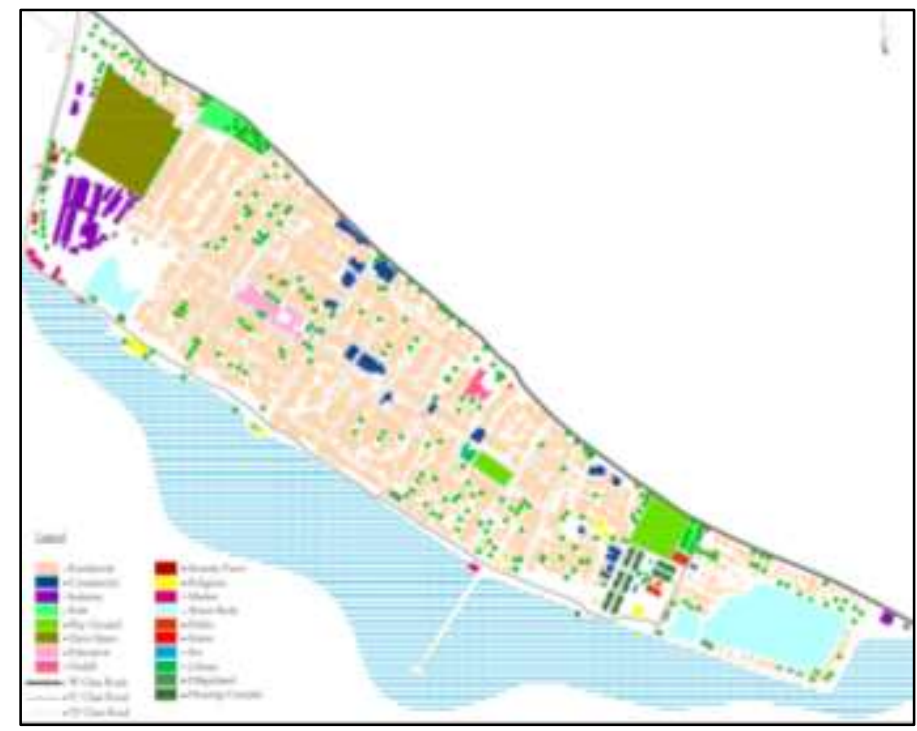

Fig 11: Layout of Gurunagar Neighbourhood Source: Author

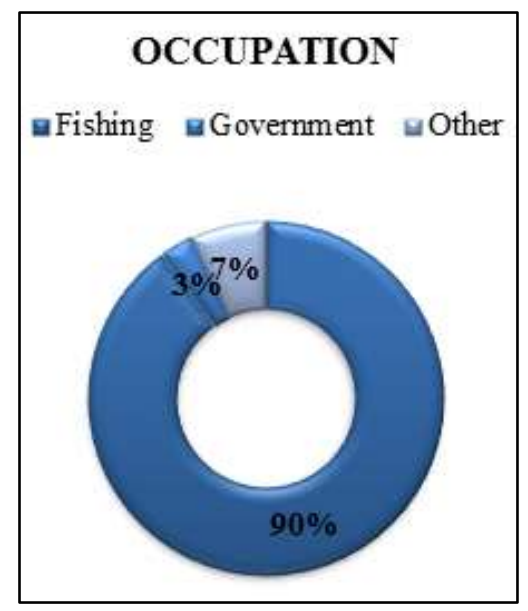

\begin{tabular}{|l|l|l|l|l|}
\hline Fishing Vilage & $\begin{array}{l}\text { Fishing } \\
\text { Population }\end{array}$ & $\begin{array}{l}\text { Fishing } \\
\text { Families }\end{array}$ & $\begin{array}{l}\text { Acfive } \\
\text { Fishermen }\end{array}$ & $\begin{array}{l}\text { Total } \\
\text { Boats }\end{array}$ \\
\hline Jaffina District & 89,190 & 21,087 & 22,182 & 7,415 \\
\hline Navanthurai & 2,152 & 425 & 562 & 87 \\
\hline Gurunagar & 9,159 & 2,312 & 3,100 & 826 \\
\hline Passaiyoor & 2,700 & 686 & 788 & 184 \\
\hline Columbuthurai & 264 & 60 & 64 & 34 \\
\hline
\end{tabular}

Fig 13: Fishing Population of Gurunagar area Source: Divisional Secretariat Hand Book

Fig 12: Main Occupation of Gurunagar area Source: Divisional Secretariat Hand Book

\section{Natural Areas Enhance the Social Life of the Neighbourhood}

The Gurunagar neighbourhood contains natural blue and green environments and is sensitive to the existing land conditions and local ecology. This may include vegetation cover, parks and play grounds, cannals, closed water body and sea side. Guunagar neighbourhood is close to the sea side. They engage in the fishing activities in the sea and they anchor their own boats along the jetty and the sea side. The natural water body plays an important role in the local neighborhood to facilitate the residents and most people to gather, chat, meet and relax. Even children play along the seaside of the neighbourhood. The part facing the sea is a significant element which gives the special character to the fishing community. 


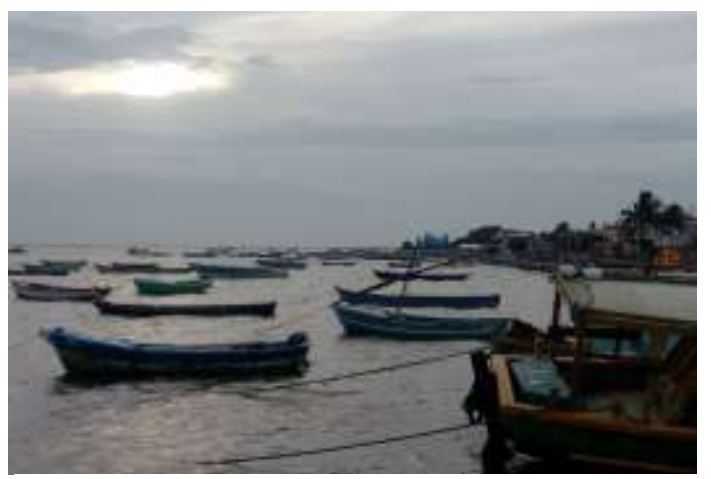

Fig 14: Sea side of Gurunagar area Source: Author

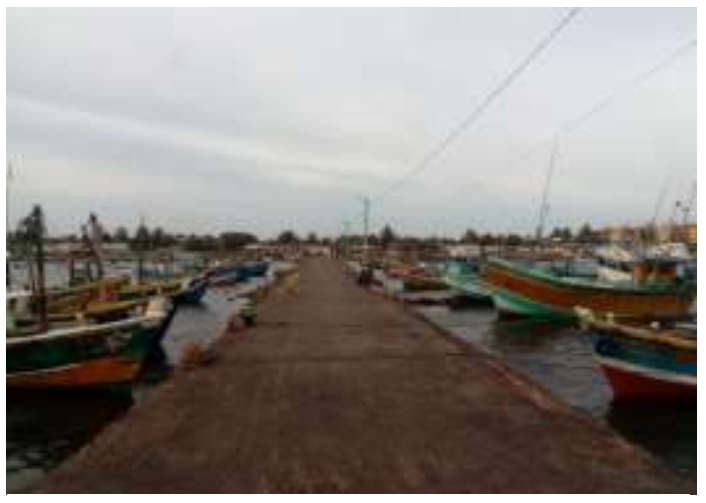

Fig 16: Anchored boats and the jetty Source: Author

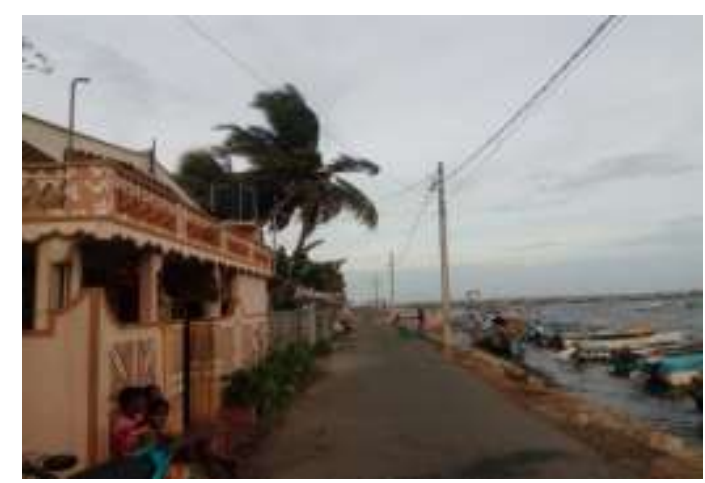

Fig 15: Houses facing to the sea Source: Author

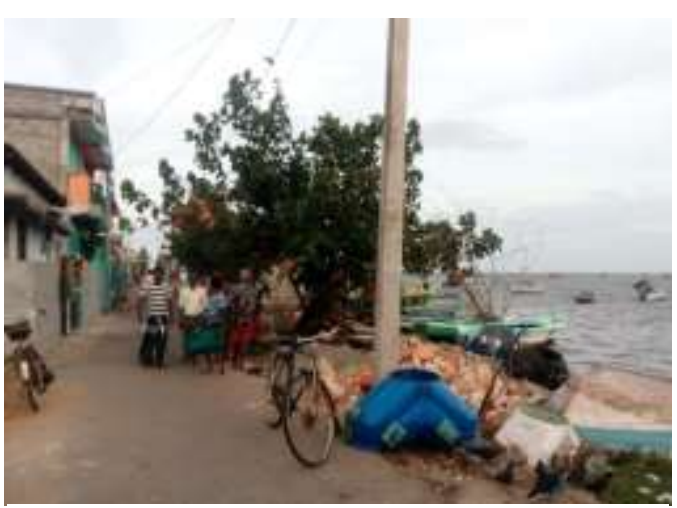

Fig 17: People gathering near the sea in the evening

Source: Author

\section{Mixed Land Use Supports the Social Life of the Neighborhood}

The neighbourhood has a mix of land uses and densities that provide options to live, learn, work, and play. More intensive land uses are connected and focused around the transit, alternative transportation modes, historical Dutch Fort, schools, markets, police station, bus stand, railway station, hospital, district secretariat office and parks. All residents of the Gurunagar neighbourhood therefore can easily access to fulfill their basic needs, daily shopping and recreational needs in their neighbourhood and close proximity of the neighbourhood regardless of mode choice.

Distance from Gurunagar neighbourhood to town center

- To Bus stand $\quad-3 \mathrm{~km}$

- To Railway Station $-2.2 \mathrm{~km}$

- Teaching hospital $\quad-2.6 \mathrm{~km}$

- Dutch Fort $\quad-800 \mathrm{~m}$

- Police Station $\quad-600 \mathrm{~m}$

- Sinnakadai Market - $600 \mathrm{~m}$

- District Secretariat - $3.8 \mathrm{~km}$ 


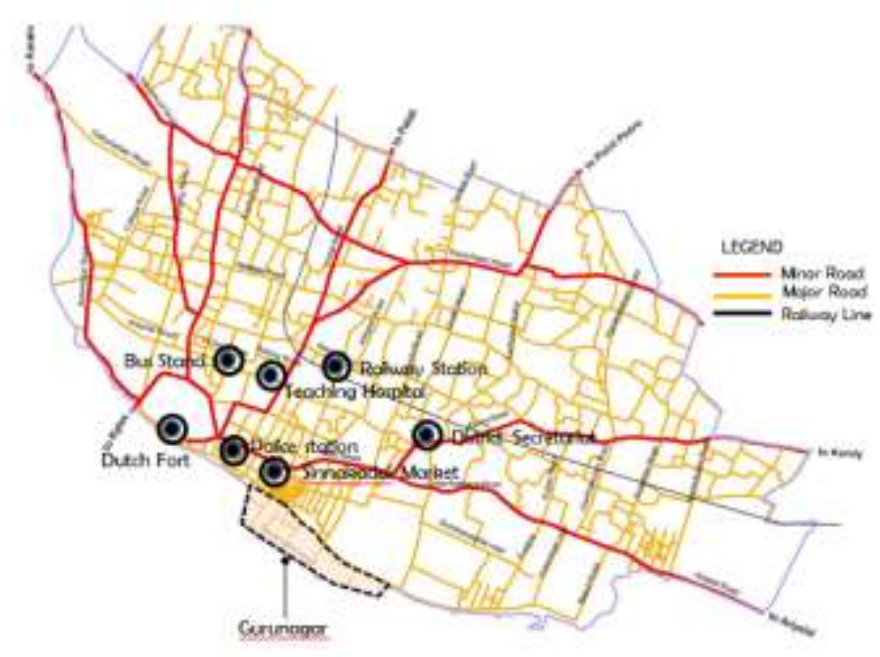

Fig 18: Locational advantage and close proximity to access the places

(Source: Author)

\section{Streets Reflect the Sense of Community and Encourages Social Life of the Neighbourhood}

Gurunagar neighbourhood offers real mobility choices for residents to travel to, from and within the neighbourhood. Streets and narrow pathways are well connected to encourage active modes of travel and enhance the local community activity and social life which happens along the streets; especially chatting, gathering, fish net mending, children playing and celebrating church festivals. They all happen along the street which reflect the functionality of street spaces. There is no traffic and parking spaces are minimal. They do not dominate the neighbourhood. This is visble in the mode of split analysis.

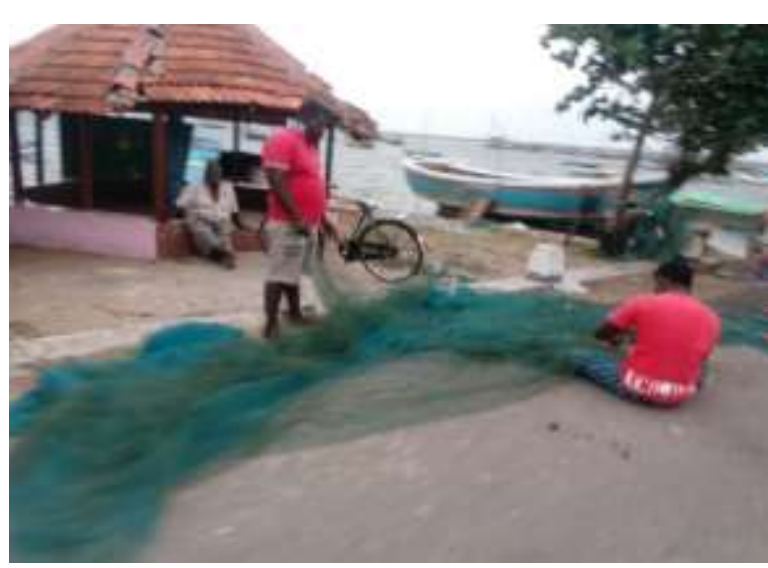

Fig 19: Fish net mending along the streets

Source: Author

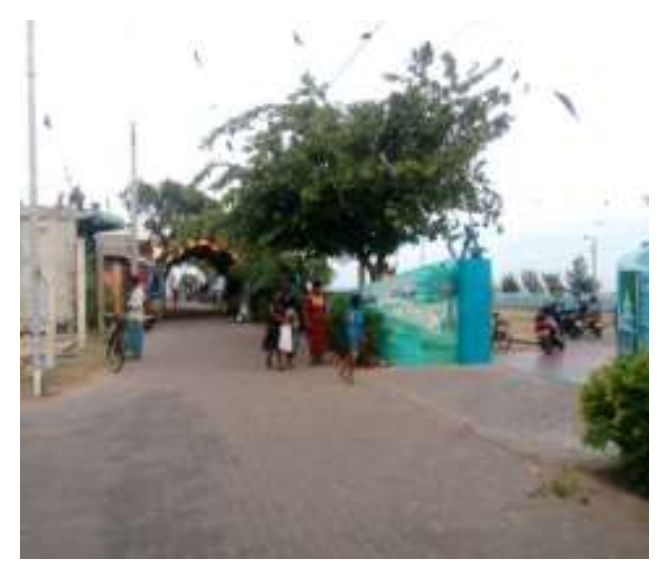

Fig 20: Celebrating church festivals along the streets

Source: Author 


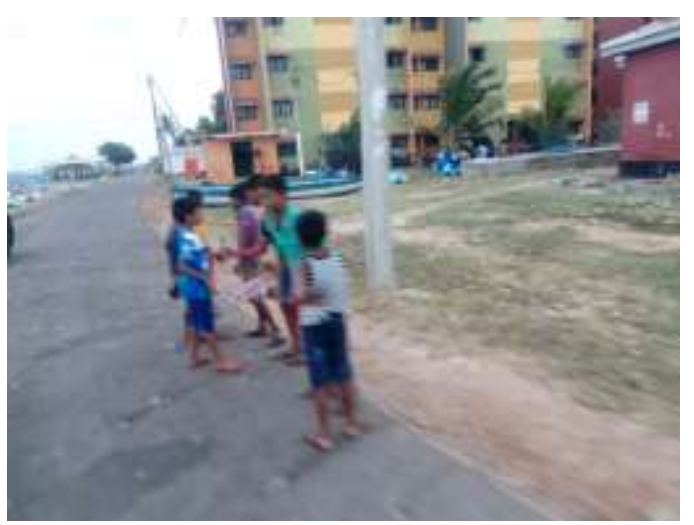

Fig 21: Children chatting along the streets Source: Author

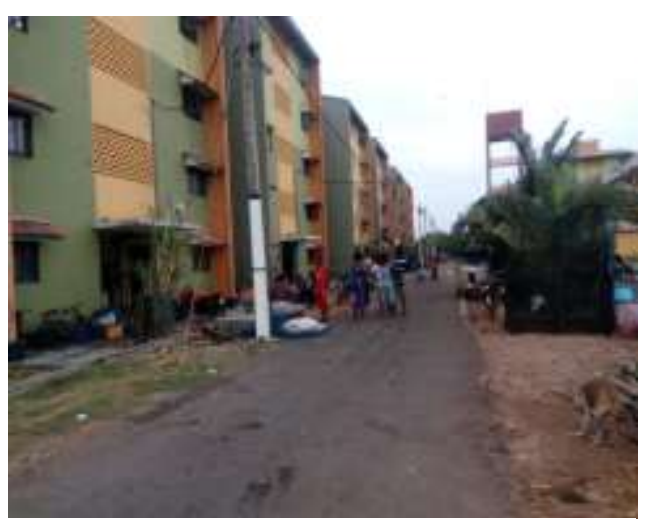

Fig 22: People chatting nearby the streets Source: Author

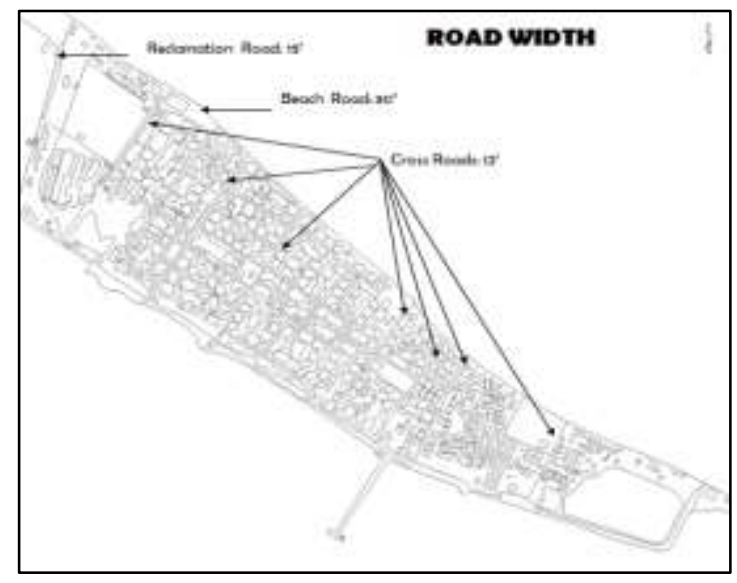

Fig 23: Street Network of the Gurunagar Neighbourhood (Source: Results from field observation, Author)

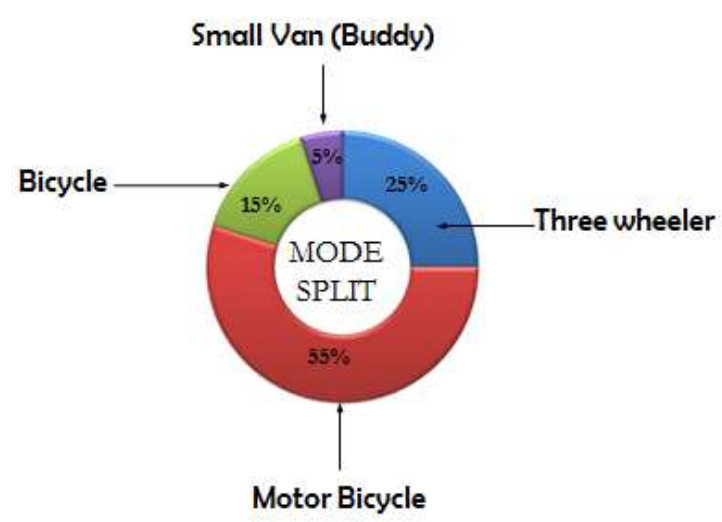

Fig 24: Mode Split of Gurunagar Neighbourhood Source: Results from analysis, Author 


\section{Compact Urban Form and Density Encourages Social Life}

Higher density housing is clustered and located with commercial and institutional uses and public transit stops. Higher density areas gradually transition again to higher density areas. Density supports a mix of uses and viable transit ridership. High population and housing density is recorded in this neighbourhood. Population density is recorded as 3661 per sq.km and housing density is recorded as 361 per sq.km.

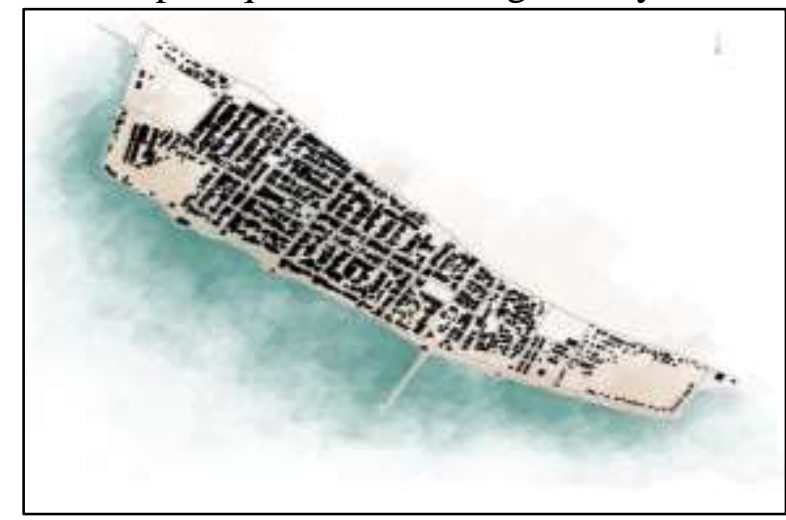

Fig 25: Nolli Map

Source: Author

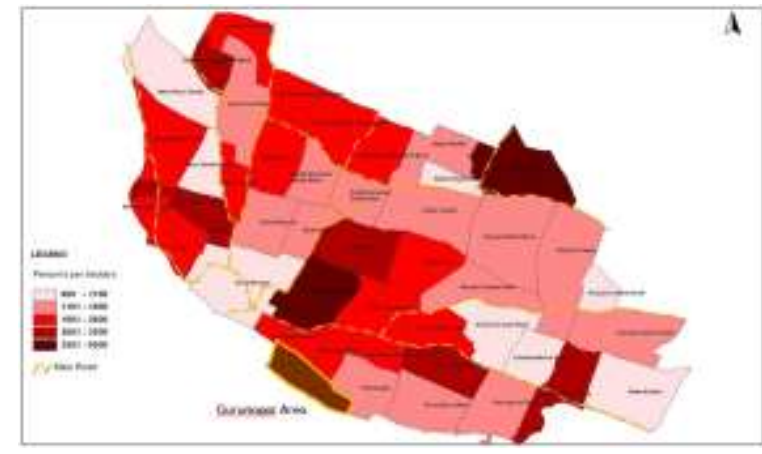

Fig 26: Population Density Map Source: Author

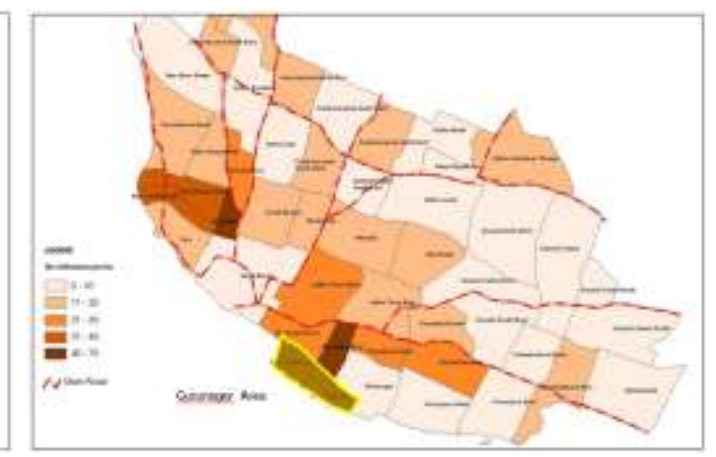

Fig 27: Housing Density Map Source: Author

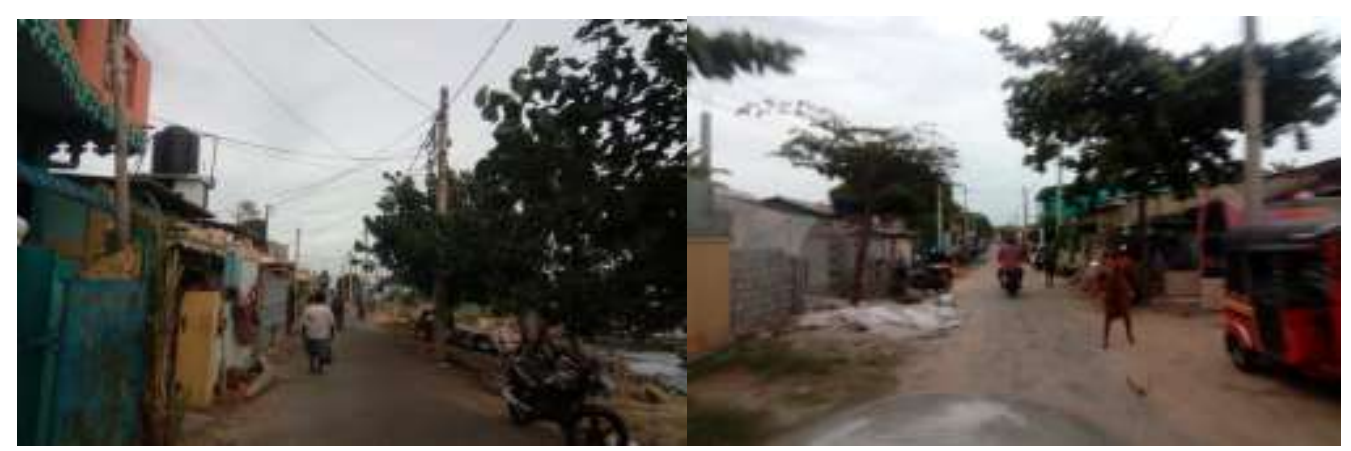

Fig 28: High dense residential area

Source: Author 


\section{Integrated Parks and Community Spaces Provide Active Space for Social Life in the Neghbourhood}

The neighbourhood offers parks and play grounds, spaces along the lagoon and some communal spaces for chatting, meeting and gathering with a variety and mix of leisure and recreational opportunities. These spaces are accessible and suitable to a range of ages and abilities. Some of the street and near to lagoon spaces provide areas to congregate, socialize, recreate, be physically active and spend time outdoors.

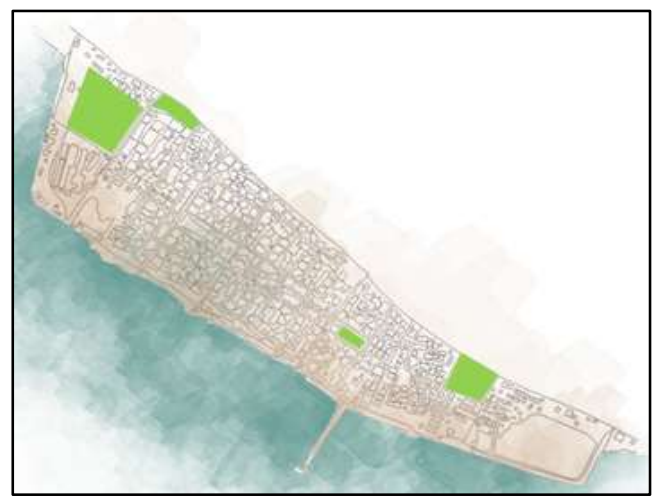

Fig 29: Location of park and play ground in Gurunagar Neighbourhood

Source: Results from analysis, Author.

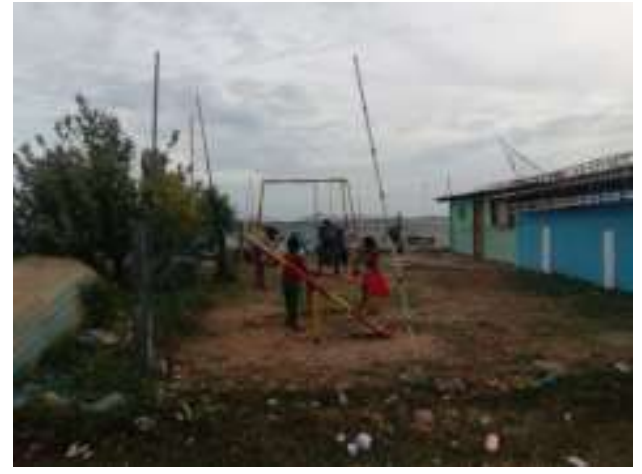

Fig 31: Play Ground Source: Author

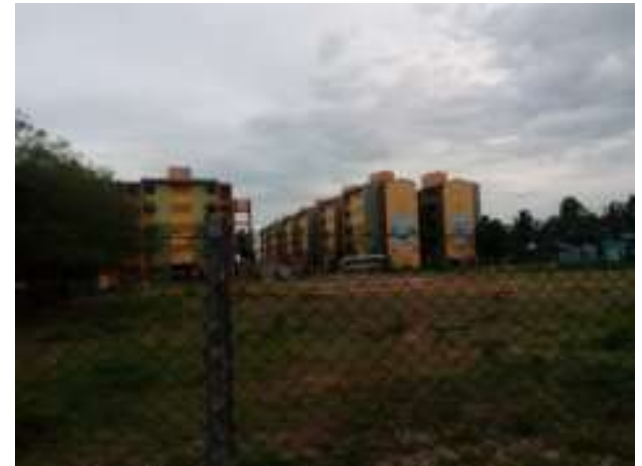

Fig 32: Play Ground Source: Author

\section{Safe is the Sign of Sense of Community and Social Life of Neighbourhood}

The neighbourhood is helping to promote overall neighbourhood safety and social interaction. Streets are meant for pedestrian and cyclist safety especially for the localist of the neighbourhood. Residents know their neighbours, feel confident to play, walk, cycle, and take transit, use neighbourhood spaces and access community amenities. Residential and Commercial areas are buffered from potentially dangerous uses such as railway tracks, industrial areas and energy facilities. The neighbourhood promotes "eyes on the street" based on livable streets. For example,

- Front porches, ground oriented dwellings and balconies on the street side of multi-family dwellings

- Design multi-family balconies to accommodate people sitting to encourage outdoor use and more eyes on the street and lane. 
Housing with useable porches or covered areas is encouraged to allow homeowners to use their front outdoor space, increasing the chance of interaction with others in the neighbourhood while maintaining 'eyes on the street'.

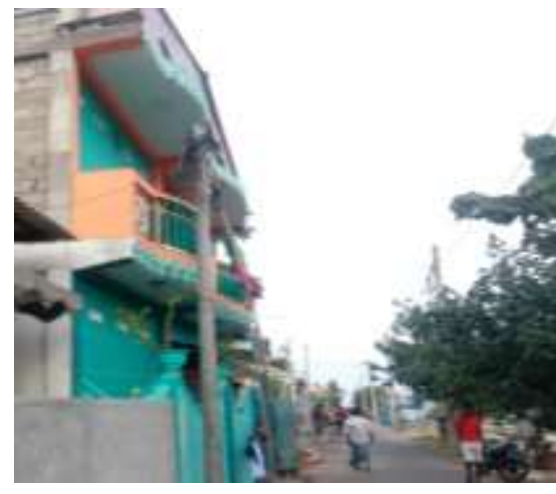

Fig 33: Front porches and balconies Source: Author

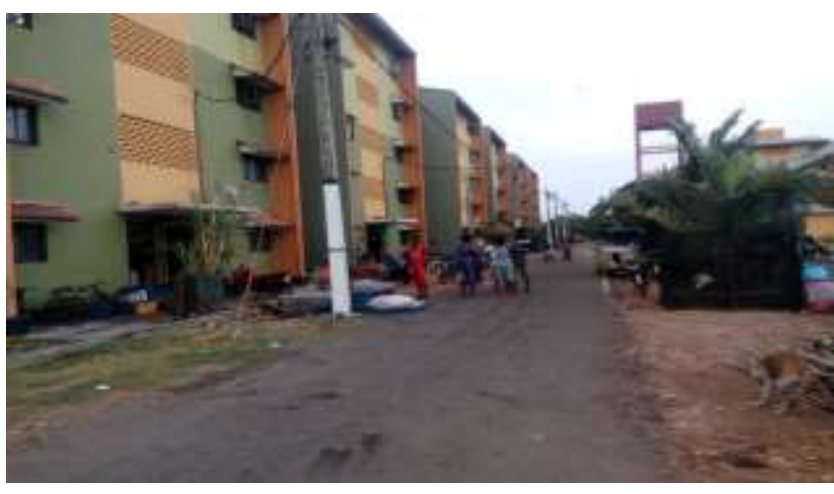

Fig 34: Design multi-family balconies Source: Author

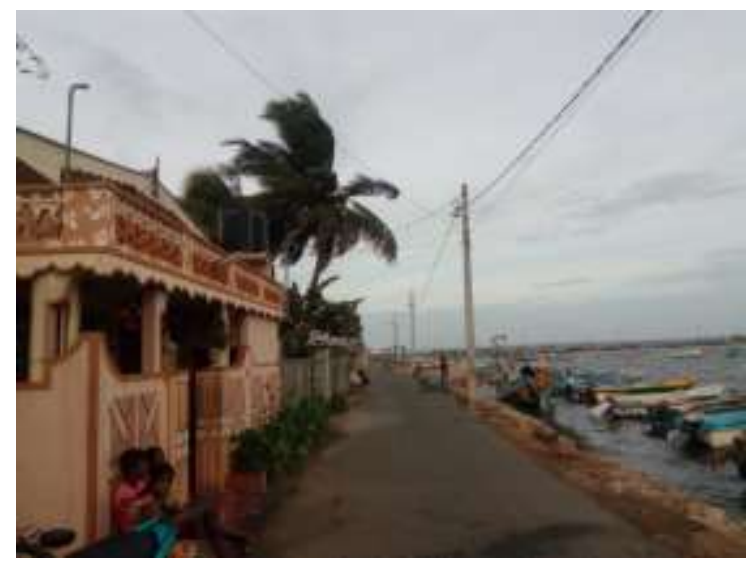

Fig 35: Neighbour feels confident to use the street Source: Author

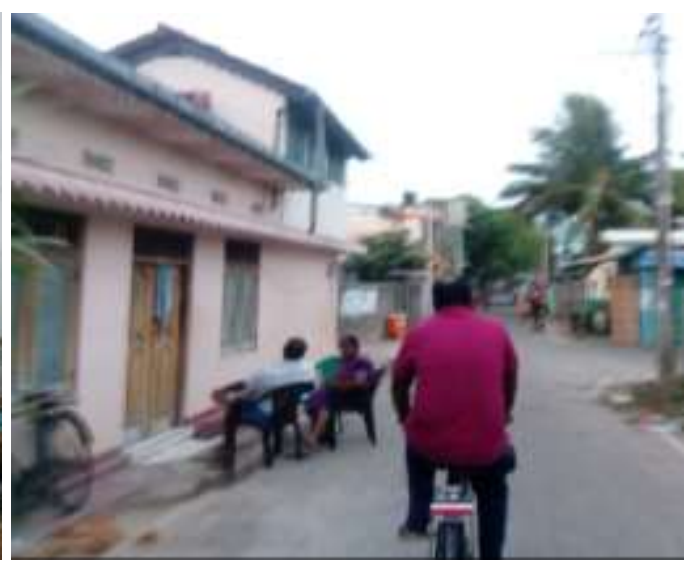

Fig 36: Streets meant for cyclist and pedestrian Source: Author

\section{Unique Neighbourhood Identty Expresses the Sense of Community}

Gurunagar neighbourhood has a distinct identity fostering community pride and a sense of belonging. Arrival features, focal points, natural elements and other symbols of the community are integrated at important intersections and other locations within the neighbourhood. High dense residence and sea-based fishing community designs express creativity and a distinct 'look and feel' for each neighbourhood, including relationships between buildings and public space, churches, size of homes, street widths, block size, choice of materials and architectural character. Especially most of the churches and statues of Christian Gods can be seen in this neighbourhood because nearly $97 \%$ of people belong to the Christian community. This is the special identity of the Gurunagar neighbourhood. 


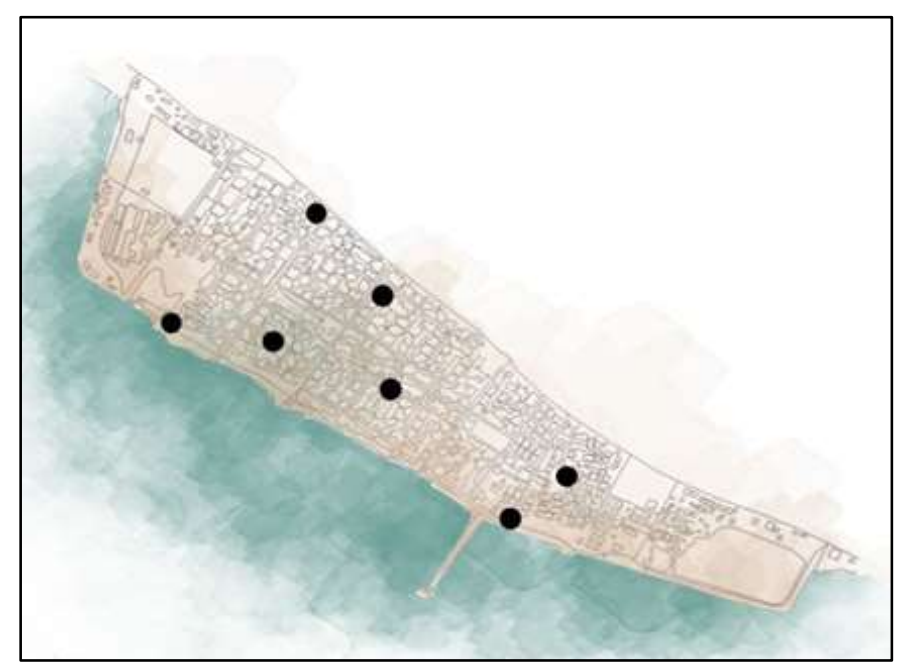

Fig 37: Location Map of Churches Source: Author

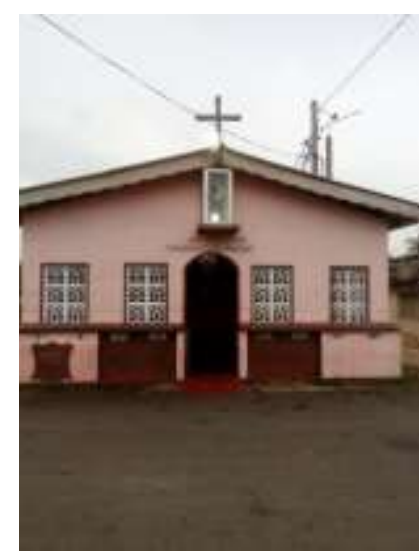

Fig 38: Small church near the jetty to worship before leaving the home for fishing

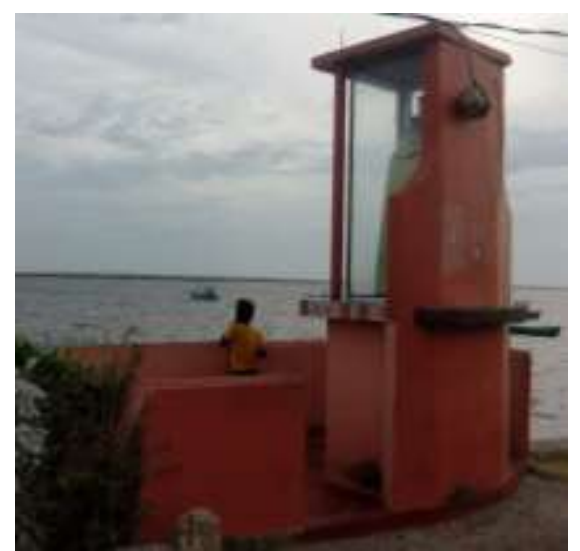

Fig 39: Statues of God can be seen along the roads Source: Author

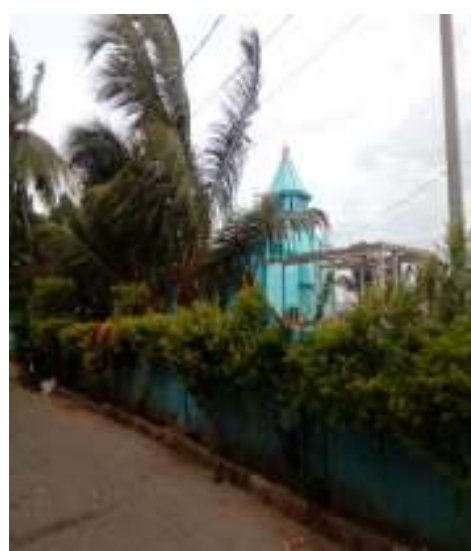

Fig 40: Main church in the Gurunagar neighbourhood Source: Author

Source: Author

The neighbourhood is located with a clear entrance (gateway feature, street, creative signage, significant landscaping) that defines the boundary which helps to enter and exit from the neighbourhood. It also contributes existing or new landmarks, views and vistas. Residential buildings are sited and oriented to overlook public streets, sea, and walkways and private communal spaces while ensuring the security and privacy of its residents. Houses and housing complexes, and entrances with stoops are preferred because they provide semi-public/semi-private spaces, encourage activity in front of units, and reduce visibility into residential units. Designed single houses and upper floors of multi-family style residential buildings are being constructed in scale with the pedestrian environment (using window details, covered entries, porches and overhangs) to ensure the family and create strong relationship. 


\section{CONCLUSIONS}

Residential environments in neighbourhoods may provide the feeling of sense of community among residents. The built environment characteristics can influence the intensity of this feeling by increasing the number of interactions and providing pedestrian-friendly environments. Interactions and weak social ties are the starting points of deeper and stronger interactions. According to the Gurunagar neighbourhood, neighbour's interactions in the Gurunagar residential environment increases the feeling of sense of community. Additionally existing walkways, informal gathering spots and sea side activities influence the social life of the Gurunagar neighbourhood especially in residential streets. Sense of community and social life of Gurunagr neighbourhood makes the Gurunagar area community healthy, safe, socially sustainable, and strengthen the local economy.

Gurunagar neighbourhood consists of a poor residential environment and functional streets which is the avenue for socializing behaviours among residents. With regard to the definitions and implications of sense of community and social life, neighbourhoods can be investigated with two different approaches: in residential streets, the sense of community can be explored, while in streets, creating vitality and encouraging social life can be considered.

There is a gap of sufficient studies, in the literature of the built environment, with regard to the social life of residential neighbourhoods. While several social life studies, in this discipline, have focused on city centres, plazas and streets, the importance of residential neighbourhoods in providing social life in cities has been neglected. With the absence of necessary public life and social bonds, many neighbourhoods and suburbs around the world have been transformed to "bedroom communities"; and accordingly, this study aims to stress the significance of residential environments in creating the social life of cities through the prospect of the given framework.

The analysis of the literature presented in this paper clarifies the meanings and implications of the concept of sense of community from a built environment perspective. Furthermore, exploring the literature with an interdisciplinary perspective shows that the proposed framework can fit the existing relevant research. The framework is offered as a way to facilitate future studies in the context of neighbourhoods through differentiating the residential environment from the nonresidential environment.

This study recommends that distinguishing the residential streets from functional streets can provide a prospect for future researchers to identify the effective elements in the public life of neighbourhoods. Several suggestions for future research can be presented. First, there is still a need for research on the built environment characteristics that encourage a sense of community in residential streets and social life in commercial streets in neighbourhoods. Since previous public life studies in neighbourhoods have sometimes misinterpreted or misplaced these two terms, this study can create a convenient standpoint for future research in this area. Future research may also investigate the extent to which neighbourhood communities can be affected by the physical environment. This study also lays a foundation for future debate over the place of local communities, in a world where residents are mostly involved in non- 
local or virtual communities. Although previous research investigations provide some insight into the application of the sense of community in neighbourhoods, there is a need for continued research on the necessity of the existence of local communities in neighbourhoods.

\section{References}

Alexander, C. (1977). A pattern language : towns, buildings, construction. New York: Oxford University Press.

Amick, D., \& Kviz, F. (1975). Social alienation in public housing: The effects of density and building types. Ekistics, 39(231), 118-120.

Appleyard, D. (1980). Livable streets: Protected neighborhoods? The ANNALS of the American Academy of Political and Social Science, 451(1), 106-117. doi: $10.1177 / 000271628045100111$

Appleyard, D. (1981). Livable streets. Berkeley: University of California Press.

Audirac, I., \& Shermyen, A. H. (1994). An evaluation of neotraditional design's social prescription: postmodern placebo or remedy for suburban malaise? Journal of Planning Education and Research, 13(3), 161-173.

Banerjee, T. K., \& Baer, W. C. (1978). The use of the neighborhood concept in professional practice. Unpublished paper, University of Southern California, Los Angeles.

Bhat, R. (2014). Understanding complexity through pattern languages in biological and manmade architectures International Journal of Architectural Research: ArchNet-IJAR, $8(2)$.

Brower, S. N. (1996). Good neighborhoods: A study of in-town \& suburban residential environments: Praeger Westport, CT.

Chermayeff, S. (1971). Shape of community : realization of human potential. Harmondsworth: Penguin.

Chermayeff, S., \& Alexander, C. (1966). Community and privacy: Toward a new architecture of humanism: Penguin.

Cochran, S. (1994). Defining, understanding, and enhancing sense of community in neighborhoods. Journal of Planning Literature, 9, 92-99.

Ewing, R., King, M. R., Raudenbush, S., \& Clemente, O. J. (2005). Turning highways into main streets: Two innovations in planning methodology. Journal of the American Planning Association, 71(3), 269-282. doi: 10.1080/01944360508976698

Francaviglia, R. V. (1996). Main street revisited : Time, space, and image building in smalltown America. Iowa City: University of Iowa Press.

Francis, J., Giles-Corti, B., Wood, L., \& Knuiman, M. (2012). Creating sense of community: The role of public space. Journal of Environmental Psychology, 32(4), 401-409. doi: 10.1016/j.jenvp.2012.07.002

Franck, K. A., \& Stevens, Q. (2007). Loose space : possibility and diversity in urban life. London: Routledge.

Gehl, J. (1980). Residential street environment. Building and Environment, 6(1), 51-61.

Gehl, J. (1987). Life between buildings: using public space: Island Press.

Gehl, J. (2010). Cities for people. Washington, DC: Island Press.

Gehl, J., \& Gemzøe, L. (2001). New city spaces: The Danish Architectural Press Cph.

Gehl, J., \& Gemzøe, L. (2004). Public spaces-public life: Arkitektens Forlag Kbh.

Glynn, T. J. (1986). Neighborhood and sense of community. Journal of community psychology, 14(4), 341-352.

Granovetter, M. (1973). The strength of weak ties. American Journal of Sociology, 78(6), l. 
Greenbaum, S. D. (1982). Bridging ties at the neighborhood level. Social Networks, 4(4), 367384.

Jacobs, A. B. (1993). Great streets. London, England: MIT Press.

Jacobs, J. (1961). The death and life of great American cities: Vintage.

Kim, J., \& Kaplan, R. (2004). Physical and psychological factors in sense of community new urbanist Kentlands and nearby Orchard Village. Environment and Behavior, 36(3), 313-340.

Lagerfeld, S. (1995). What main street can learn from the mall. Atlantic-Boston, 276, 110-121.

Lund, H. (2002). Pedestrian environments and sense of community. Journal of Planning Education and Research, 21(3), 301-312. doi: 10.1177/0739456x0202100307

McMillan, D. W., \& Chavis, D. M. (1986). Sense of community: A definition and theory. Journal of community psychology, 14(1), 6-23.

Mehta, V. (2007). Lively streets: Determining environmental characteristics to support social behavior.Journal of Planning Education and Research, 27(2), 165-187. doi: 10.1177/0739456x07307947

Mehta, V. (2008). Walkable streets: pedestrian behavior, perceptions and attitudes. Journal of Urbanism: International Research on Placemaking and Urban Sustainability, 1(3), 217245. doi: $10.1080 / 17549170802529480$

Mehta, V. (2009). Look closely and you will see, listen carefully and you will hear: Urban design and

social interaction on streets. Journal of Urban Design, 14(1), 29-64. doi: $10.1080 / 13574800802452658$

Mehta, V. (2013). The street : a quintessential social public space. Abingdon, Oxon ; New York, NY:

Routledge.

Mehta, V., \& Bosson, J. K. (2009). Third places and the social life of streets. Environment and Behavior, 42(6), 779-805. doi: 10.1177/0013916509344677

Montgomery, J. (1998). Making a city: Urbanity, vitality and urban design. Journal of Urban Design, 3(1), 93-116. doi: 10.1080/13574809808724418

Moustafa, Y. M. (2009). Design and neighborhood sense of community: An integrative and cross- culturally valid theoretical framework. ArchNet-IJAR, 3(1), 71-91.

Mullan, E. (2003). Do you think that your local area is a good place for young people to grow up? The effects of traffic and car parking on young people's views. Health Place, 9(4), 351-360.

Orvell, M. (2009). Constructing main street: Utopia and the imagined past. Public Space and the Ideology of Place in American Culture, 3, 97.

Robertson, K. A. (2004). The main street approach to downtown development: An examination of the four-point program. Journal of Architectural and Planning Research, 21(1), 5573.

Ross, C. E., \& Jang, S. J. (2000). Neighborhood disorder, fear, and mistrust: The buffering role of social ties with neighbors. American Journal of Community Psychology, 28(4), 401420.

Sarason, S. B. (1974). The psychological sense of community: Prospects for a community psychology: Jossey-Bass.

Southworth, M. (2005). Reinventing main street: From mall to townscape mall. Journal of Urban Design, 10(2), 151-170. doi: 10.1080/13574800500087319

Talen, E. (1999). Sense of community and neighbourhood form: An assessment of the social doctrine of new urbanism. Urban Studies, 36(8), 1361-1379. doi: $10.1080 / 0042098993033$ 
Talen, E. (2000). Measuring the public realm: A preliminary assessment of the link between public space and sense of community. Journal of Architectural and Planning Research, 17(4), 344-

360.

Talen, E. (2003). A matter of priorities: New Urbanism and community life. Places, 15(3), 7780.

Unger, D. G., \& Wandersman, A. (1985). The importance of neighbors: The social, cognitive, and affective components of neighboring. American Journal of Community Psychology, 13(2), 139-169.

Wolshon, B., \& Wahl, J. (1999). Novi's main street: Neotraditional neighborhood planning and design.

Journal of urban planning and development, 125(1), 2-16. 